\title{
MHD発電ダクト用セラミック製絶縁壁の 熱応力破壊に関する検討
}

\author{
正員 野 村 修 身 (電緿研)
}

\section{1. まえがき}

日本において研究開発中の MHD - 汽力発電システ 么は，石油の然焼ガスを作動流体として MHD 発電を 行ない，更にその排ガスを在来の汽力発電システムの ボイラに導いて，汽力タービン発電を行なうシステム である(2)。との作動流体（石油燃焼ガスにカリウム化

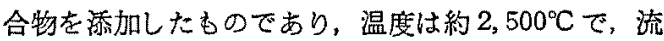
速は約 $700 \mathrm{~m} / \mathrm{s}$ を必要亡されている(2) 必要な発電ダクトの壁として, 研究開発の最初汇考案 されたのは，作動流体との接触面を厚い耐火断熱れん がで構成した「ホット壁」であった。このような発電 ダクト壁は，壁からの熱損失が少なく，更に壁面が高 温であるために発電特性が良いので，高い熱効率をる つ発電ダクトではあるが，他方，耐火断熱れんがが作 動流体の温度㧍よで流れによって極めて短時間に消耗 してしまう(実験結果 ${ }^{(1)}$ にれれは数分間)。現在におい ては，実用の発電機に必要な数干時間の運転をホホッ 卜壁で実現できる見通しは立っていない。

それゅえに，長時間耐久性を満定できるような発電 ダクトとして，作動流体との接触面保水冷金属を使っ たヘグ壁(4)，また住作動流体による摩耗や腐食に対し て耐えられるように，常温とほ浔同等の機械的強度お 上び化学的安定性をむつ温度 (数百 ${ }^{\circ} \mathrm{C}$ ) 亿泠却する構造 を古吉，耐熱七ラミックス系材料(ベリリア磁器など) で発電ダクトの壁面を粗成したコールド壁(3)が考案さ れ，それぞれ長時間運転の可能性が示された。

ところが，上記のように低温の壁では壁からの熱損 失が極めて大きく(数百 $\left.\mathrm{W} / \mathrm{cm}^{2}\right)$, 更住壁の表面上に

Thermal Stress Fracture to Ceramic Insulating Wall in an MHD Generation Duct. By Osami Nomura, Member (Energy Conversion Section, Electrotechical Laboratory, Ministry of International Trade and Industry)

野村衖身；正員，電子挍街総合研究所エネルギー变換研究室
生じた冷い境界層により隣接した電極の表面が覆われ るので，電極電圧降下が極めて大きくなることも相ま って発電特性が悪くひいては発電効率す低いので, 実用の発電譏に必要な性能を満足させるのは極加て困 難である。

上記の理由のため，実用の発電ダクト壁としてセミ ホット壁が必要とされだ6)。との方式は，壁の温度を 使用材料化よって定まる適当な温度 (千数百 $\left.{ }^{\circ} \mathrm{C}\right)$ となる ように精密に制御するととによって，ホット壁のよう な壁面の大きな損耗を抑えると同時に，ペグ壁やコー ルド壁で生ずる冷い境界層による悪影響を防ぐすので ある。

前論文 ${ }^{(5)}$ にて，セミホット壁用材料としては，耐熱 性, 耐摩耗性および耐食性に優れたちみつ質の耐熱セ ラミックス系材料が最む有望であるが，ての材料は熱 応力に対して弱いために，発電ダクト壁は熱芯力破液 が生じない上うに十分の注意をはらって製作する必要 があるととが示された。更に理論解析により、MHD 発䉓機の運転時に，発電ダクト壁素子の内部発生す る熱応力が自身の破買を引き起てさないような限界の 条件を求める方法が開発され，その限界条件がセミ本 ット発電ダクト壁に要求される項目の一つであると提 案された。

本論文は，上記の研究を進めて，セミホットMHD 発䉓ダクト壁用の材料として最む一般的なちみつ質の マグネシアセラミックスで製作した発電ダクト壁につ いて，熱応力破㯰に対する検討を行なったすのであ る。ここで検討対象としたセミホット発電ダクト壁 は，壁面を細かく分割して多くの素子で構成したもの である。検討方法は以下の手順で行なった。まず発篭 ダクト壁のモデルを想定し，上記の方法により限界条 件を求めてその特徽を明らかにした。同時に，素子内 部の熱态力分布を計算し熱応力破塄状態を予想した。 
更に，以上の理論解析結果を発電ダクトモデルの実験 結果と比較検討した。

\section{2. 理論解析方法}

セミホット発電ダクトを構成する素子においては， 作動流体 (温度約 $2,500^{\circ} \mathrm{C}$ ) 乙接触する面は千数百 ${ }^{\circ} \mathrm{C}$ 程度に加熱され，反対面は水冷された支持体に接する ので素子の内部の温度こう配は極めて大きい。

この素子の熱応力破壊を防ぐためには，素子内部に 生ずる熱応力が可能な限り小さくなるように発電ダク 卜壁を構成する必要がある。その基本的な要件は，素 子の温度変化に伴って生ずる熱变形を機械的に拘束し ないことである ${ }^{(9)}$ 。その方法に洁，素子とその支持体 との間に極めて柔軟な介在物を介して接着する方法 ${ }^{(5)}$ あるいは両者を緩いかん合方法により接続し，少々の 熱変形を許容できるようにした方法(6)なざが考案され ている。このような取り付け方法によれば，素子の物 性值が均一でしかむ温度依存性がなければ，定常状態 に招いては素子に温度こう配をいかに生じさせようと 6素子内部伤熱応力は発生しない(9)。しかし，本論文 で検討対象のマグネシアセラミックスは，第2図に示 すように極めて物性值の温度依存性が大きいので，上 記のような支持方法であ大きな熱応力が発生して素子 が破塄する恐れがある。

理論解析方法としては，上記の取り付け状態にある 発電ダクト壁素子に，定常状態で生じる熱応力を数值 計算により見積って卖子材料の破壊強度と比較し，素 子内のすべての部分で熱㤂力の值が破填強度より小さ ければ，長時間運転が可能な発笔ダクトであると判定 した。との考察基準基づき, 発電ダクト壁菜子の限 界条件の計算方法が開発され，更汇計算精度が検討さ れた ${ }^{(5)}$ 。理論解析方法は前論文 ${ }^{(5)}$ 亿詳しく述べられて いるので，本論文では理論解析の主要部分である熱応 力計算方法の概要を述べるにとどめる。

理諭解析に必要な熱応力計算を行なうためには，数 值計算モデルを考案して，まずその温度分布を計算 し，そのうえで計算された温度分布に基ついて熱忘力 計算を行なう。

$\langle 2 \cdot 1\rangle$ 温度分布計算方法温度分布計算方法の 概要は下記のとおりである。温度分布計算モデルは， 第 1 図に示すように素子の形状は直方体（幅： $2 A$, 厚さ：B) で，作動流体倿触する面 $(y=0)$ は一定 温度 $T_{W}$ であり，反対面 $(y=B)$ は一定温度 $T_{b}$ の 支持体汇相対して次式で示す熱放散条件が成り立つ。

$$
q=\left[\frac{\partial \theta}{\partial y}\right]_{y=B}=-h\left(\theta_{0}-\theta_{b}\right)
$$

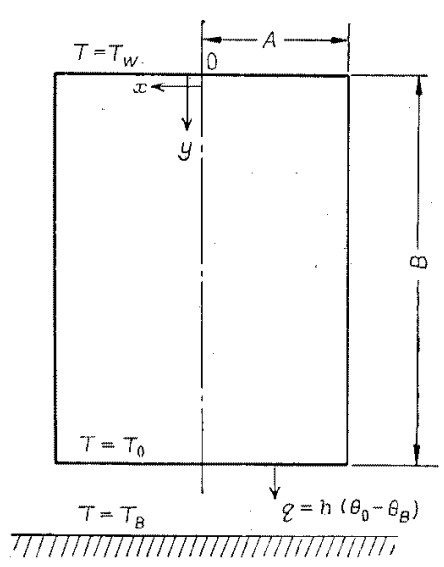

$T:$ 温度, $q:$ 熱流束, $\theta=\int_{T_{s}}^{T} \lambda d T$

$\theta_{0}=[\theta] T=T_{0}, \theta_{B}=[\theta] T=T_{B}$

第 1 図 発箒ダクト壁素子の計算モデル

Fig. 1. Calculation model for insulating wall element of MHD generation duct.

ここで，qは放散熱流束であり， $\theta$ は次式で定義され る。 $\theta_{0}$ および $\theta_{b}$ 岋それぞれ $y=0$ およよ゙ $y=B$ での $\theta$ の值である。

$$
\theta=\int_{T_{s}}^{T} \lambda d T
$$

ここで， $\lambda:$ 素子材料の熱伝導率， $T:$ 温度，

$T_{s}:$ 基準温度

素子の側面 $(x=A)$ では，他の素子の側面と接して いるので断熱状態であるとみなした。それゆえに温度 分布は一次元亡なり，熱関数 $\theta$ によって間接的に次式 で表わされる。

$$
\begin{aligned}
& \theta=\theta_{W}-\frac{N}{1+N} \xi\left(\theta_{W}-\theta_{b}\right) \\
& \text { ここで, } \theta_{W}=[\theta]_{T=T}, \quad \theta_{b}=[\theta] \ldots \ldots \\
& N=h \cdot B, \quad \xi=y / B
\end{aligned}
$$

素子の底部 $(y=B)$ における温度を $T_{0}$ とし， $T_{0}$ に相当する熱関数の值を $\theta_{0}$ とすれれば次式で示され る。

$$
\theta_{0}=\frac{\theta_{W}+N \theta_{0}}{1+N}
$$

$\langle 2 \cdot 2\rangle$ 熱応力計算方法 熱応力計算には有限要 素法 ${ }^{(7)}$ を応用した。本論文の検尌対象であるマグネシ アセラミックスに抬いては，すへてての物性值の温度依 存性が極めて大きいためである。物性值の温度依存 性を考慮した熱応力計算方法は数件発表されている $か^{(12)}$, い゙れもごく一部分の物性值が温度给存性を示 すのみ滴用できる方法であって，本諭文の検詩には 適用できない。本論文の目的に対しては，有限要素法 
以外化適当な熱応力計算方法は見いだせなかっだ(5)。

素子内部に発生する熱㤂力は，平面ひずみ状態(9)に ある平面熱㐫力と仮定した。平面ひずみとは，長手方 向端面の影璠のない応力状態であるが，熱応力計算の 結果汪りり，限界条件の決定に関係する最大引張热心 力は素子の中央付近住することがわかったのて，本 論文の目的のためには素子の長手方向端面の影皚を無 視しても，最大引張岕力の計算にはさしつかえないと みなされだ。計算結果によれば，長手方向の絴横此が 0.5 上り小さければ端面の影叟はないものとみなされ た。また，熱㤂力は素子の中心線付対して左右対称で あるため，第1 図に示された菜子の断面の左半分を計 算範囲とした。

数值計算精度を検討した結果 ${ }^{(5)}$ ，乙の計算範团の要 素分割数は， $x$ 万向に 5 等分割就よび $y$ 力向に 13 等 分割しした。それ沛えに，要菜数洁 65 お上び節点数 は 232 となった。ただし，要菜は 8 節点長方形要素 (不完全二次要素(7) 使用した。

\section{3. 理論計算の結果および検討}

第2图のマグネシアセラミックスの物性值を使って 計算した限界条件を第 3 図の实線で示す。ここで加熱 面温度 $T_{W}$ を $1,400 \mathrm{~K}$ とした。との温度以上ではマグ ネシアセラミックスにクリープが生ずるため ${ }^{(8)}$ ，加熱 面温度加 $1,400 \mathrm{~K}$ 以上の場合には，素子内部で 1,400 K以上の部分には定常熱応力が生じないとみなされる ので，実効的汇綎横比 $\gamma(=B / 2 A)$ 加変わったとみな される。

第3图の実線に上れば、ケが 0.5 以下の場合には限 界条件が $\gamma$ にはにとんど門関係であって，更に素子の 冷却面の温度を $650 \mathrm{~K}$ 以上に保つ必要がある。他方,

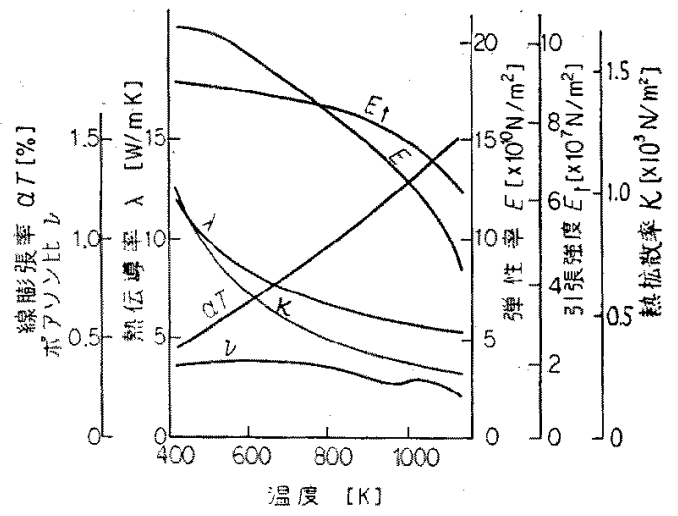

第 2 图 マグネシアセラミックスの物性值

Fig. 2. Physical properties of magnesia ceramics.

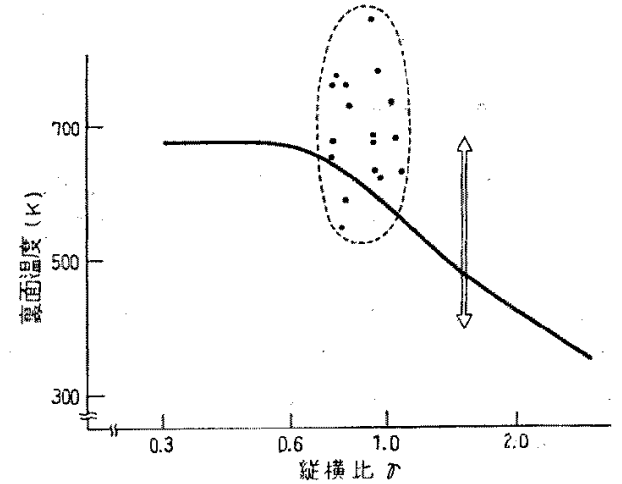

第3囡定常運転中の発電ダクト壁子小条件 Fig, 3. Conditions of wall element of MHD generation duct model in steady state.

$\gamma$ が 3.0 以上で限界条件として $T_{0}$ が $350 \mathrm{~K}$ 以下で あるととがわかる。すなわち，冷却体温度 $T$ 。を 350 Kと仮定すれは，弥子と冷却体の間愠度差をすたせ る必要がないととを意味する。言い替えれば，素子を 文持体隹取り付ける場合に，素子の熱变形を拘束しな い方法でありさえすれば良く，両者の間に熱抵抗を付 ける必要がないので, 取り付りに対する制限は少なく なると考元られる。しかし，てのためには素子の紑横 比を3.0以上之，かなり細長くしなりればならない。

以上の結果を更に詳細に検討するために，熱㤁力の 分布図を求めた。縦横比

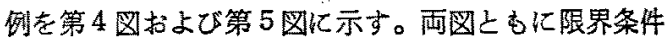
に近い状㮩である。同図内の矢印の方向および長さ は，それぞれ矢目の交点における主㐫力 ${ }^{(9)} の$ 方向およ び大きさの相対値を示し，更に外向きの矢印は引張応 力および内向きの矢印は圧縮応力を表わす。

熱応力分有図(第4 图扰よび第 5 因)によれば，素子 の周辺では王縮応力が主であって, 中央付近は引張応

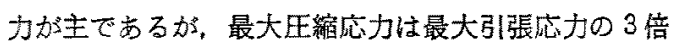
は越えないことがわかる。ところで，本諭文で検討し たマグネシアセラミックスでは, 厈縮強度が引張強度 ○ 10 倍程度 ${ }^{(8)}$ であるから, 限界条件は最大引張熱応 力と引張強度を比較すれば定まる。また素子の中央部 分では， $\gamma=1.0$ においては最大引張応力か $x$ 万向と $y$ 方向ともにほとんど同じ大きさであるが， $\gamma=0.5$ においては $y$ 方向の応力は極放て小さく， $x$ 万向のみ であるので，言い替えれば $\gamma=0.5$ 以下であると中央 部の熱応力汶して $x$ 方向端面の影響はによんどない あの上考えられる。限界条件図(第2図)においても が 0.5 以下では限界值がほほ一定となっており，上記 の考察を裹付けている。 


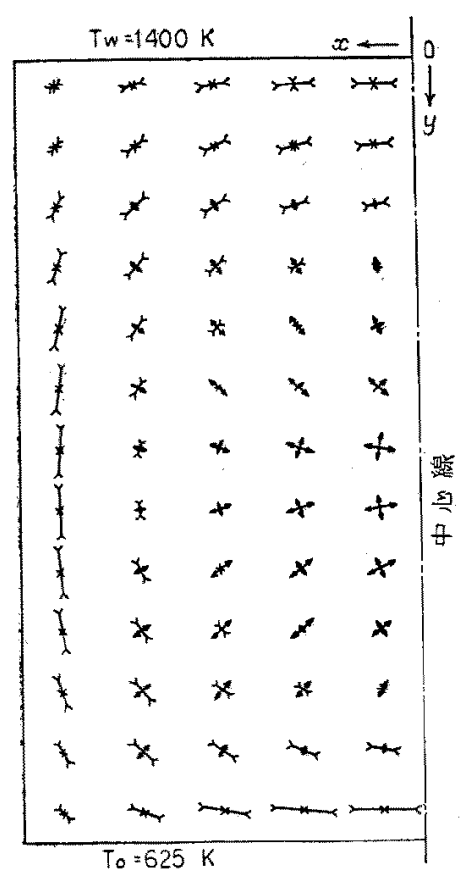

第 4 図熱応力分布図(維横比=1.0)

Fig. 4. An example of thermal stress distribution when aspect ratio is 1.0 .

熱废力分布図により素子が熱応力により破流する状 況を想定すれば，以下のようになる。

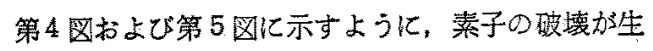
ずる直前の状態に执いてす最大王縮応力が最大引張応 力の3倍は越えないととがわかる。としるが，本論文 の検討対象であるマグネシアセラミックスは，正縮強

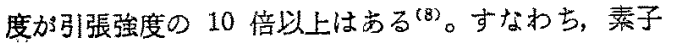
の破壊は引張感力に生ずると考えられる。とてろが， 引張応力の最大僬は素子の中央付近に生ずる。それゆ えに，菉子の酎力が全体に均一であるならば素子の破 壊は中央付近上り生じ站めるむのと考えられ，その結 果, 中央部分上り大きく分割する形態となると想定さ れる。次章に示すモデル实験化いて破壦した素子の 状態を見ると，上記に想定されたような中央より2分 割状態となっており，上部の考察の妥当性定証明して いる。

\section{4. モデル実験}

前章さでにおいては，マグネシアセラミック製の発 電ダクト壁素子の熱応力破壊状況が理論的に解析され た。本章においては，この結果を奏験的に袷証する。 前章で示された熱応力破壊を生じない条件を実駼的

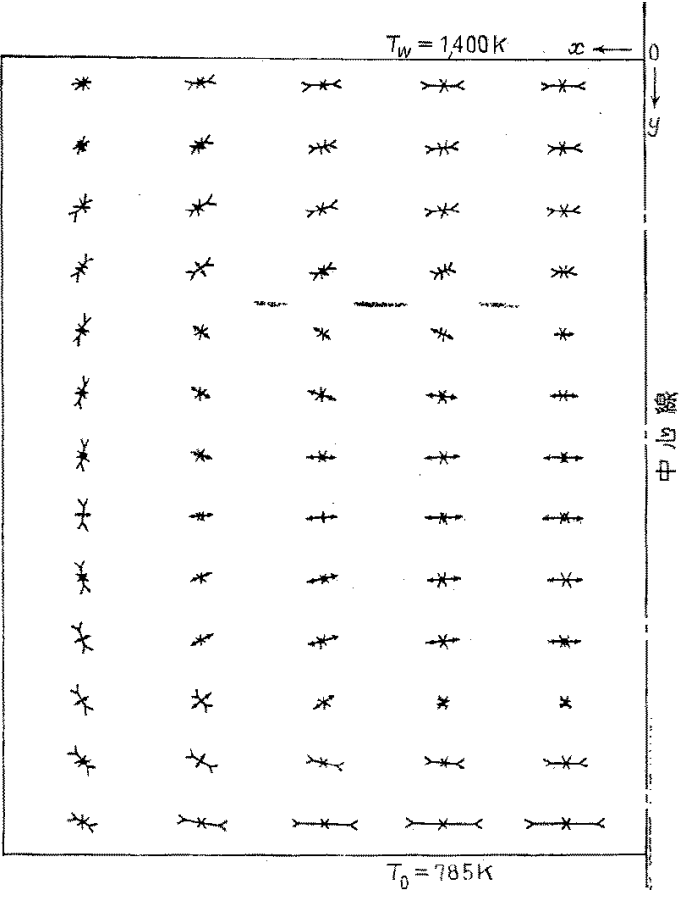

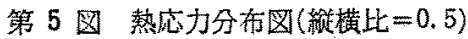

Fig. 5. An example of thermal stress distribution when aspect ratio is 0.5 .

に検証するだめには，素子と支持体の熱伝详係数が正 確に規定でき，しかも素子の熱変形を拘束しないよう な取り付け方法により，発電ダタトモデルを作製しな ければならない。とこるが筆者の調査によれは，上記 の条件を満たし，しかす作動流体の流れなどによる力 儿耐えるような機械強度が十分にある取り付け方法は まだ開発されていない。をれ沛えに，素子と支持体の 間が接触状態代あるような発霞ダクト壁（この場合， 熱変形汇対する拘束はないとるなされる)の破燷状態 を榆討することにより，理諭解析結果を検趾吉る。し 加し，この上うな発電ダクト壁においては，素子上支 持体の間の熱伝達特性が不安定であるので，素子の破 壊状態は統計的に険討した。

〈4.1〉 モデル発電ダクトの構造 実験用のMHD 発電ダクトのエデル䋓縁壁を第6図に示す。同图に示 された素子の間の水冷金属片は，之の表面任生ずる冷 い境界層处り囊子の表面老婹い，作動流体の主流が もつ高い温度より素子を保護する㗢きをむつ。菜子は その突起部分を水冷金属片のくぼみに引っ封けて脱落 をしない上うに支持してあり，水潘基盤との接着仙し ていない。そ枕えに，素子の熱変形に対しては少し の拘柬もない香のとみなした。素子の表面比いては 


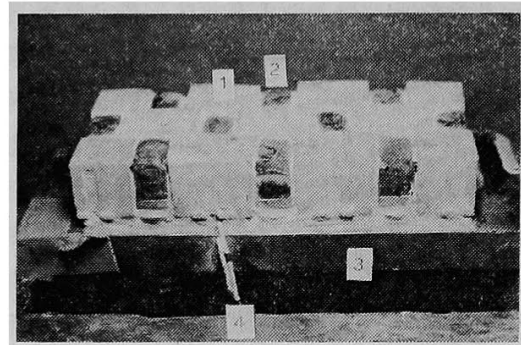

1：素子， $2:$ 水冷金属片， $3:$ 基盤， 4 : 熱電対

第 6 図 MHD 発電ダクトモデル 絶縁壁（実験前）

Fig. 6. Model insulating wall of MHD generation duct (pre-test).

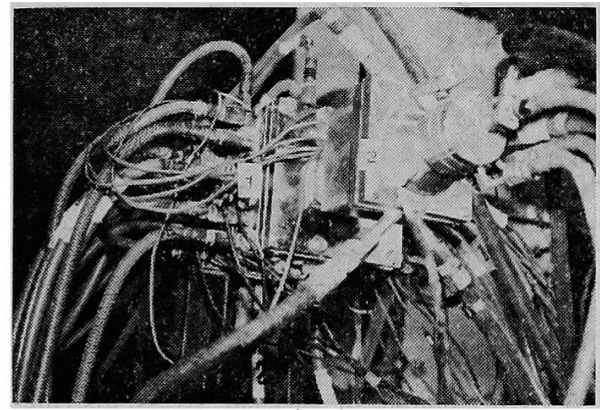

1: MHD 発電ダクトモデル, 2: 燃焼器

第 7 図 試験装置全景

Fig. 7. Test equipment all over.

ステンレス鋼製の基盤滵着させられてあり，側面と 金属片の間は約 $0.5 \mathrm{~mm}$ のすきまがある。それゆえに 素子のダクト壁断面方向の熱流に比べて素子の側面方 向の熱流は無視し, 素子の温度分布は一次元であると みなした。

試験された素子は，ちみつ質のマグネシアセラミッ クスで製作されており，厚さ $15 \mathrm{~mm}$ ，幅 $10 \mathrm{~mm}$ およ び長さ $20 \mathrm{~mm}$ である。裹面より $7 \mathrm{~mm}$ と $11 \mathrm{~mm}$ の 位置で素子の中心線上に達する穴をあけ，白金熱電対 接点をそう入し素子内部の温度分布を測定した。

このモデル壁で構成される作動流体の流路は, 長さ $195 \mathrm{~mm}$ ，幅 $40 \mathrm{~mm}$ および高さ $10 \mathrm{~mm}$ となった。 実験装置の全景を第 7 図に示す。

〈4-2〉 実験条件 作動流体はプロパンとメチル アルコールを純酸素で然焼したガスに，水酸化ナトリ ウムを重量で $1.7 \%$ 添加したむのであり，定常流量は $17.1 \mathrm{~g} / \mathrm{s}$ である。作動流体の諸物性值を理論計算 ${ }^{(11)}$ よ り求め, 流速を推定した結果約 $400 \mathrm{~m} / \mathrm{s}$ であった。こ の值では作動流体の流れによる摩耗は小さいとみなさ れる。

実験時間としては, 流量の上昇に 2 時間, 定常運転
に 6 時間半抢よび下降に 45 分をかけた。なお, 流量 を変化するときは，流量の変化割合が一定となるよう に調節した。

定常運転中に，左右壁に設けた電極を通じて外部電 源より $3 \mathrm{~A}$ の電流を流し電流の影響を調べた。

〈4-3〉実験結果 モデル発電ダクトの運転中に, 素子に取り付けた熱電対により素子の温度分布を測定 したが，その最高温度における状態を第 3 図中の・印 で示す。運転中における表面温度の最高值は，素子材 料にそ性が表われる温度 $(1,400 \mathrm{~K})$ を超えているの で，同図の・印が示す縦横比は，前章で既に述べたよ うに素子の実効縦横比である。素子のなかには温度測 定を行なっていない素子もあるか，運転中の最高温度 状態における全素子は，大略，同図の銷線で囲んだ範 囲にあるむの之みなされる。それ沛えに，発電ダクト モデルの素子のなかには破壊が生じているものむある と考えられる。破壊の生じる条件をむった素子は，第 3 困の鎖線の中で限界条件を示す線（実線）で区切ら れた下部の状態にある素子と考えられるので，鎖線で 囲まれた面積に対する実線下部の面皘の割合が，素子 の延べ総数に対する破壊を生じた素子の数の割合之同 等であると考えた。ての考察に従って破壊割合を推定 すると約 $20 \%$ となった。

他方，実験後の分解点検の結果によれば，破壊を生 じた素子の延べ個数は 6 個であった。乙の実験使用 した素子は延へ 28 個であるから,すなわち破壊割合 は $21.4 \%$ であった。この結果は上記の推定破壊割合 にほぼ一致を見ており，理論解析結果の妥当性を示し ていると言える。

実験後の素子の破壊状態はほとんどの素子において 中央付近より割机ており，前章の熱応力分布の計算結 果(第 4 図㧍よび第 5 図)より推定した破壊形態之一致 している。

運転中に測定された素子の温度分布より，素子と基 盤との間の熱伝達係数を求め, その熱伝達係数を使っ て素子の表面温度が $1,400 \mathrm{~K}$ になったときの裹面温度 を計算すると第 3 図の矢印で示される範囲となった。 この矢印の位置が示す䋛横比 (1.5) は，素子の短い側 の長さと厚さの比である。さきに述べたように，素子 の縦横比が小さくなると限界条件は縦横比亡無関係之 なるので，素子の限界条件は縦横比の大きな側の值で ほぼ決定されるとみなした。第 3 図の矢印の位置より 作動流体を上昇する途中に执いても，素子のうちの幾 つかは既に破壊を生じていたものと推定できる。

第 8 図に実験後の壁の外観を示す。実験中におい て，作動流体を通じて流した電流による影響と見られ 


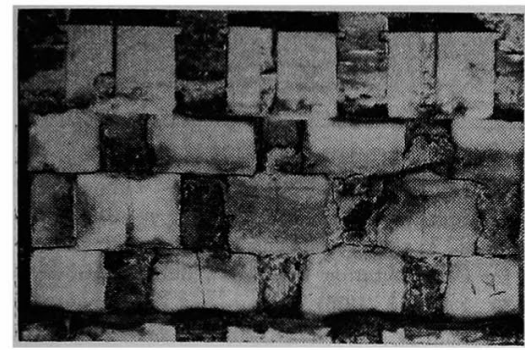

第 8 図 実験後の発電ダクトモデル壁

Fig. 8. Model insulating wall of MHD generation duct at after-test.

るむのは，電流を流した電極付近に生じた局所的な溶 融のみであった。この事実は以下の理由によると考え られる。

この発電ダクトモデルでは，壁表面が耐熱セラミッ クス製であるため，壁表面温度は極めて高い（表面状 態より見て千数百 ${ }^{\circ} \mathrm{C}$ 程度はあったとみられた)。それ ゆえに，セラミックスの表面では電流集中は生じなか った。ただし，電流を流し込んだ電極は水冷ステンレ ス鋼製であるので，温度は数百 ${ }^{\circ} \mathrm{C}$ みられ，電極付近 には電流集中が生じたあのと考えられる。電流集中が なければ，作動流体中を流机る電流による作動流体の 温度の上昇は無視できる程度である(10)。それゆえに， 壁素子の表面に対して電流による熱応力破壊への影響 は実質的にないむのとみなされる。

本実験においては，素子と支持体の間が接触状態で あるから，両者間の熱伝達係数は大きなばらつきを生 じていると思われる。素子の間における破壊状態に大 きな差異があるのは，との理由によるものと考えられ る。第 3 図の実線で示されるように，水冷金属の支持 体が保たれる通常の温度(約 $350 \mathrm{~K}$ ) よりも，素子の裏 面温度は高い温度を保つ必要があるので，ての両者間 は適当な熱抵抗を持ち, しかもその值は正確に調節で きなければならない。それ沛えに，素子の熱変形を拘 束しない方法であって，しかむ両者間の熱抵抗の值を 正確保つことのでき，そのうえに十分に機械的強度 のある支持方法を開発し，更にその熱的特性を明確に はあくする必要がある。

\section{5. まと め}

本論文では, 火力発電所において在来の汽力発電プ ラントの前段機に使われるMHD 発電機の発電ダクト 壁を検討対象とした。この MHD - 汽力複合発電シス テムはベースロード用に使われるむのであるので，発 電ダクト壁はカリウムを含んだ高温 $\left(2\right.$ 千数百 $\left.{ }^{\circ} \mathrm{C}\right)$, 高 速 (約 $1,000 \mathrm{~m} / \mathrm{s}$ ) の燃焼ガスにさらされながら，数干
時間にわたり安定した発電性能を維持しなければな らない。このように厳しい条件を満たすむのとして, ガスとの接触面に耐熱セラミックス系材料（マグネシ アなど）を使った発電ダクト壁の開発が進められてい る。しかし，てのような材料は熱応力破壊汇対して弱 いので，ての面からの考慮をはらって発電ダクト壁を 構成する必要がある。そのためには発電ダクト壁面を 小さな素子に分割し，それぞれの素子の熱変形が拘束 されないような支持方法が考案されている。

本論文では, 上記の構造を持ち, 壁の材料としてマ グネシアセラミックスを使った発電ダクト壁の熱応力 破壊について, 理論的および実験的な検討を行ない, 以下の結論を得た。

（1）発電ダクト壁素子が熱応力破壊を生じないよ うにするためには，素子の泠却面温度を所定の值以上 に保つ必要がある。理論解析により, との冷却面温度 の下限値が求められ，素子の紩横比(高さ/幅)が小さ くなるほど高くなることがわかった。その様子は下記 のとおりである。

（i）素子の縦横比が 0.5 以下では，この下限值は 綐横比にかかわらず約 $650 \mathrm{~K}$ である。素子内部の 最大引張応力が引張強度を超えない条件により， 下限值が決められるが, 後述するように素子の中 央付近に最大引張応力が生ずるので, 縦横比が 0.5 以下では中央付近の応力に対する端子の影響 がほとんどないてとを示している。

（ii）素子の縦横比が 3.0 以上では，ての下限値が $350 \mathrm{~K}$ 以下となる。むし, 素子の支持体の温度が $350 \mathrm{~K}$ であるならば, 素子之支持体の間に熱抵抗 が不要であり，発電ダクト壁の製作条件が少なく なる。

（2）上記の理論解析に用いた熱态力計算方法を使 って熱応力分布を求めた。その結果, 最大引張応力が 中央付近におよび最大圧縮応力が周辺に生じ，しかも 後者は前者の 3 倍は越えないととがわかった。それゆ えに, 素子の熱応力破壊は中央付近より割れる形であ ると推定された。発電ダクトモデルの実験により生じ た破壊状態は，上記の理論計算により推定した状態と 良く一致した。

（3）実験中に測定したダクトモデルの壁素子の温 度分布と, 上記の理論解析結果より得られた素子の冷 却面温度の下限值を比較検討して, 実験により破壊を 生じる素子の割合は約 $20 \%$ であると推定した。実験 後の観察により，素子の $21.4 \%$ 亿破壊が生じている ことがわかり，さきの推定值と良く一致した。

(4) 発電ダクトモデルの実験中に，ダクト壁に設

昭 $56-3$ 
けたステンレス鋏製の笔極を通じて，外部電源より内 部の作動流体江電流を流し, 電流に上る熱㤂力破塤に 対する影響を調べた。その結果，電極の表面温度が低 かったため電極付近には電流が集中して生じたと見ら れる嗄賃が認められたが，その他の部分には電流によ る影響は認められなかった。

（5）熱応力破壇を生じない発電ダクトを作るだ には，発電ダクト壁菜子の冷却面温度を正確保つこ とが必要である。そのた的は，熱伝達特性が安定し た素子の支持構造を開発する必要性が示された。

終りに，本研究は通商産業省工業技術院で計画した 大形省エネルギー技術の研究開発の一項目である電磁 流体発電の研究開発の一部であり，研究の機会を与え られ，更に有益な助言をいただいた電子技術総合研究 所等々力 達エネルギー部長(現，当所次長)，本間环 也エネルギー変換研究室長（現，筑波大学教授）始 め，エネルギー変換研究室の各位に感謝いたしま す。

(昭和 54 年 5 月 21 日受付, 同 55 年 7 月 2 日再受付)

\section{文献}

（1）伏見，他：「MHD 発電機電試 2 号機の実馱，32，477 (昭 43-5)

(2) 電気学会編: 奄気工学ハンドブック, p.1210 (昭 53)

(3) Okuo, et al.: "Development of Ceramic Insulating Walls for Long Duration Channels", Bull. Electrotech, Lab., 39, 133, 213 (1975)

(4) Fushimi, et al.: "Construction of MHD Generator with a Large Scale Superconducting Magnet (ETL Mark V)", 13 th. Symp. MHD, IV, 2 (1972)

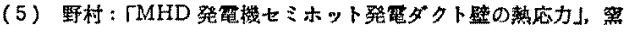

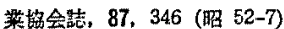

（6）野村：「MHD 発觜機の表面冷却型せミホット発電チャネル

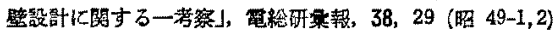

（7）ツィーキィサィッッ・チューン，吉識 訳：マトリクス有限 要䒺法, p. 12 (昭 48) 培風館

（8）功刀編：無機材料科学, p. 310 (昭 47) 趾文堂新光社

(9) 竹内: 第応力, p. 13 (昭 46) 日新出版

(10) 奥尾・永田：[MHD 発電用政熱材料のアークスポットによ

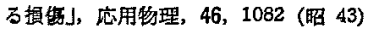

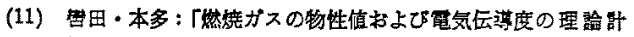
算]，奄気試験所策報，32，98（昭 43）

(12) 例え仗, Minardi : "Effect of Variations in the Coefficient of Thermal Expansion upon Thermal Stress", AIAA J., 4, 542 (1966) 